\title{
PENGARUH LAZIZMU TERHADAP PENGENTASAN KEMISKINAN DI KOTA PEKALONGAN
}

\author{
Saebani, SS, M.Si. ${ }^{1}$, Moegiri, SE, M.Si. ${ }^{2}$ \\ 1,2 Proram Studi Ekonomi Syariah FEB UMPP \\ Korespondensi email: saebani123@gmail.com
}

\begin{abstract}
Abstraksi
Penelitian ini dilaksanakan dengan tujuan untuk mengetahui dampak adanya lembaga amil zakat Muhammadiyah yang ada di kota pekalongan terhadap pengentasan kemiskinan di kota pekalongan. Kemiskinan adalah suatu masalah yang sulit untuk dipecahkan. Maka dari itu perlu adanya lembaga yang berperan seperti lazis dalam membantu memecahkan permasalahan kemiskinan ini, karena kalau mengandalkan pemerintah saja kurang mampu untuk mengentaskan kemiskinan. Penelitian ini menggunakan metode regresi berganda. Pekalongan yang merupakan kota yang dihuni banyak orang islam dengan profesi kebanyakan adalah pedagang. Ini merupakan potensi yang sangat besar untuk mengumpulkan pundi-pundi zakat. Zakat ini merupakan suatu kewajiban setiap pemeluk agama islam dalam hubungannya dengan makhluk social. Pekalongan juga mempunyai penduduk miskin yang juga tidak kalah jumlahnya dengan penduduk yang berkeblebihan harta. Maka dari itu peneliti akan menganalisa bagaimana usaha pemerintah maupun organisasi kemasyarakatan dalam mengentaskan kemiskinan yang ada di kota pekalongan.
\end{abstract}

Kata Kunci : zakat, kemiskinan, lazismu

\section{PENDAHULUAN}

Pekalongan dikenal masyarakat luas dengan kota batik, di sini sebagai kota batik tentu saja masyarakat kota pekalongan mempunyai usaha batik. Pengusaha batik di koa pekalongan sangatlah banyak, baik dikalangan pribumi maupun suku pendatang (Suku Arab dan suku China), dengan demikian menambah kota pekalongan hidup sebagai kota jasa. Kita tahu bahwa kota yang hidup seperti kota jasa misalnya maka peredaran uang sangatlah besar sehingga mengakibatkan kesejahteraan kota pekalongan sangat tinggi.

Peredaran uang yang besar tersebut tidak merata, namun beberapa orang saja yang mengenyam kesejahteraan itu. Memang sungguh ironis, pekalongan yang merupakan kota dagang tetapi masyarakatnya banyak yang belum mengenyam kesejahteraan tersebut, masyarakatnya masih banyak yang miskin. 
Usaha pemerintah kotapekalongan dalam mengentaskan kemiskinan sudah banyak diantaranya dengan menciptakan tenaga kerja dengan memberikan kesempatan masyarakat untuk ikut belajar di Balai Latihan Kerja dengan biaya Rp. 0 alias gratis bahkan setelah selesai belajar siswa yang lulus diberikan uang modal. Selain Balai Latihan Kerja Pemerintah memberikan kesempatan kepada masyarakat untuk berdagang di jalan-jalan (Pasar Tiban) untuk menaikkan kesejahteraan masyarakat kota pekalongan.

Dari berbagai usaha pemerintah maupun organisasi masyarakat untuk mengentaskan kemiskinan tersebut kota pekalongan masih menyisakan banyak masyarakat miskin yang belum tersentuh kesejahteraan. Dengan adanya usaha dari pemerintah dan oraganisasi masyarakat tersebut mampu menekan angka kemiskinan yang ada di kota pekalongan.

Penelitian ini melibatkan 2 (dua) mahasiswa yang masih aktif, dengan tugas membantu penyebaran kuesioner dan rekapitulasi data.

Dengan adanya lembaga amil zakat yang didirikan oleh ormas di sini Perserikatan Muhammadiyah atau LAZISMU yang diharapkan mampu meneken angka kemiskinan tersebut untuk itu penelitian ini membahas tentang pengaruh lazismu terhadap pengentasan kemiskinan di kota pekalongan. Penelitian ini menganalisa pengaruh lazismu terhadap pengentasan kemiskinan di kota pekalongan.

\section{TINJAUAN PUSTAKA}

Dalam pandangan islam, Allah adalah pemilik mutlak alam semesta dan isinya, sehingga harta kekayaan yang dimiliki manusia hanyalah titipan yang sementara, di mana manusia di beri kekuasaan untuk mengelolanya. Sebagai pihak yang di beri kekuasaan, tentu manusia harus mengikuti kehendak yang mutlak dari harta kekayaan tersebut kepada allah, baik dalam perolehan, pendayagunaan maupun penyaluran/ pengunaannya. Allah SWT telah berkata dalam firmannya surat at-taubah ayat 103.

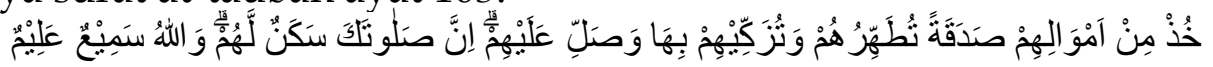

"ambillah zakat dari sebagian harta mereka, dengan zakat itu kamu membersihkan dan mensucikan mereka dan mendoalah untuk mereka. Sesungguhnya doa kamu itu (menjadi) ketenteraman jiwa bagi mereka. dan Allah Maha mendengar lagi Maha mengetahui". (Q.S. at-taubah : 103)

Dari ayat di atas dapat kita ambil kesimpulan bahwa zakat tidakhanya membersihkan harta yang kita miliki saja, melainkan juga membersihkan diri kita dari penyakit hati dan dari dosa-dosa kecil berka do'a dari orang yang menerima zakat. Hadis rasulullah juga mengatakan. abu hurairah berkata, rasulullah bersabda: "siapa yang di karuniai oleh allah kekayaan tetapi tidak mengeluarkan zakatnya, maka pada hari kiamat nanti akan di datangi oleh seekor ular jantan gundul yang sangat berbisa dan sangant menakutkan dengan dua bintik di atas dua matanya". (HR. Bukhari )

Adapun yang berhak menerima zakat, telah disebutkan oleh Allah SWT dalam surat At Taubah ayat 60 . 


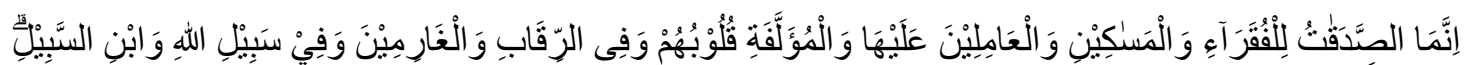

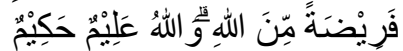

“Sesungguhnya zakat itu hanyalah untuk orang-orang fakir, orang miskin, amil zakat, yang dilunakkan hatinya (mualaf), untuk (memerdekakan) hamba sahaya, untuk (membebaskan) orang yang berutang, untuk jalan Allah dan untuk orang yang sedang dalam perjalanan, sebagai kewajiban dari Allah. Allah Maha Mengetahui, Mahabijaksana."

Pembangunan manusia berbeda dengan pembangunan fisik, pembangunan fisik bias diukur dengan angka namun pembangunan manusia tidak bias diukur dengan angka seperti pemikiran Adam Smith bahwa ada campur tangan dari kekuatan yang tidak terihat oleh mata manusia (the other hand).

Dalam penelitian (Nurzaman 2010), membahas tentang pengaruh efektifitas zakat produktif dalam meningkatkan kesejahteraan penerima zakat (mustahik) dengan menggunakan indicator kesejahteraan yang tidak hanya diukur dengan indicator ekonomi tetapi juga mencakup pendidikan dan kesehatan yang terangkum dalam Indeks pembangunan manusia (IPM).

Walaupun penelitian semacam ini sudah dilakukan namun di kota pekalongan khususnya Lazizmu belum ada yang meneliti, untuk itu perlu diadakan penelitian secara khusus pengaruh keberadaan lazismu terhadap pengentasan kemiskinan di kota pekalongan.

\section{METODE PENELITIAN}

Sumber data yang digunakan dalam penelitian ini adalah sumber data primer, yaitu dating langsung kepada narasumber dengan membagikan kuesioner yang harus diisi oleh nara sumber langsung.

Penelitian ini dilaksanakan di kota Pekalongan dan dikhususkan para mustahik dari pentasharufan LAZISMU kota Pekalongan dengan rentang waktu tahun 2020.

Variable dalam penelitian ini terdiri dari :

Variable terikat yaitu variable yang dipengaruhi oleh variable bebas, dalam penelitian ini peneliti menggunakan pengentasan kemiskinan.

Variable bebas yaitu variable yang mempengaruhi variable terikat. Dalam penelitian ini ada 2 variabel bebas, yaitu : Potensi zakat dan Pendayagunaan zakat

\section{Metode analisis dan pengolahan data}

Instrumen penelitian adalah suatu alat yang digunakan untuk mengukur fenomena alam maupun sosial yang diamati dan secara spesifik semua fenomena ini disebut variabel penelitian. Instrumen atau alat ukur dalam penelitian ini berupa kuesioner yang berisi beberapa pertanyaan. Penyusunan kuesioner penelitian ini didasarkan pada konstruksi teoritik yang telah disusun sebelumnya. Kemudian dikembangkan dalam indikatorindikator dan selanjutnya dikembangkan dalam beberapa pertanyaan. Instrumen ini disusun dengan menggunakan skala likert. 
Adapun kisi kisi dalam penelitian ini adalah sebagai berikut: Skala Pengukuran Instrumen Indikator-indikator diukur menggunakan skala likert yang mempunyai lima tingkatan preferensi yang masing-masing memiliki skor 1-5 dengan rincian sebagai berikut: Skor Keterangan 1 Sangat Tidak Setuju (STS) 2 Tidak Setuju (TS) 3 Netral (N) 4 Setuju (S) 5 Sangat Setuju (SS).

Uji Coba Instrumen Penelitian, kuesioner penelitian sebelum digunakan dalam penelitian harus diuji coba terlebih dahulu. Uji coba instrumen dilakukan untuk mengetahui apakah instrument yang disusun benar-benar merupakan hasil yang baik. Kuesioner ini akan diujicobakan pada 30 orang responden. Uji coba instrumen dalam penelititan ini adalah:

\section{Uji Validitas dan Reliabilitas}

Uji Validitas Uji validitas digunakan untuk mengukur sah atau tidaknya suatu kuesioner. Suatu kuesioner dikatakan valid jika pertanyaan pada kuesioner mampu mengungkapkan sesuatu yang akan diukur oleh kuesioner tersebut. Alat uji validitas yang digunakan dalam penelitian ini adalah Confirmatory Facor Analysis (CFA). Untuk memudahkan dalam melakukan uji validitas, maka digunakan analisis faktor yang ada pada software SPSS 16. Uji validitas instrumen penelitian ini menggunakan korelasi pearson.

Uji reliabilitas adalah pengujian yang dilakukan untuk mengetahui konsistensi dan stabilitas dari hasil pengukuran dari waktu kewaktu. Sebuah kuesioner dikatakan reliabel atau handal jika jawaban seseorang terhadap pernyataan adalah konsisten atau stabil dari waktu ke waktu (Ghozali, 2011). Uji reliabilitas dalam penelitian ini menggunakan metode alpha cronbach dengan aplikasi SPSS, suatu konstruk atau variabel dikatakan reliabel jika nilai Cronbach Alpha (a) > 0,60 (Ghozali, 2011).

Setelah diuji validitas dan reliabilitas, tahap selanjutnya adalah uji asumsi dan uji regresi berganda dengan menggunakan spss 16.

\section{HASIL DAN PEMBAHASAN}

Uji Validitas dan Reliabilitas

Hasil dari uji validitas dan reliabilitas dari variable pengentasan kemiskinan adalah:

Uji validtas dari suatu variable dianggap lolos apabila memenuhi syarat yaitu nilai korelasi harus lebih besar dari table r. table $\mathrm{r}$ dari 99 data yang yang diujikan didapat nilai 0.1956. dilihat dari table di atas, diperoleh nilai $\mathrm{r}$ hitung adalah item $1=0.682$, item $2=0.729$, item $3=0.748$, item $4=0.732$, dan item $5=0.758$. dari nilai tersebut dapat disimpulkan bahwa instrument variable pengentasan kemiskinan adalah valid.

Uji reliabilitas dari suatu variable dianggap lolos apabila nilai alpha lebih besar dari 0.7, sedangkan nilai yang didapat dari uji reliabilitas variable pengentasan kemiskinan adalah 0.774 . 


\section{Hasil dari uji validitas dan reliabilitas dari variable Potensi zakat adalah}

Uji validtas dari suatu variable dianggap lolos apabila memenuhi syarat yaitu nilai korelasi harus lebih besar dari table r. table $r$ dari 99 data yang yang diujikan didapat nilai 0.1956. dilihat dari table di atas, diperoleh nilai $\mathrm{r}$ hitung adalah item $1=0 . .684$, item $2=0.724$, item $3=0.797$, item $4=0.761$, dan item $5=0$. 682. dari nilai tersebut dapat disimpulkan bahwa instrument variable potensi zakat adalah valid.

Uji reliabilitas dari suatu variable dianggap lolos apabila nilai alpha lebih besar dari 0.7, sedangkan nilai yang didapat dari uji reliabilitas variable potensi zakat adalah 0.707 .

\section{Hasil dari uji validitas dan reliabilitas dari variable Pendayagunaan zakat adalah:}

Uji validtas dari suatu variable dianggap lolos apabila memenuhi syarat yaitu nilai korelasi harus lebih besar dari table r. table $r$ dari 99 data yang yang diujikan didapat nilai 0.1956. dilihat dari table di atas, diperoleh nilai $\mathrm{r}$ hitung adalah item $1=0.685$, item $2=0.639$, item $3=0.765$, item $4=0.799$, dan item $5=0$. 682. dari nilai tersebut dapat disimpulkan bahwa instrument variable pendayagunaan zakat adalah valid.

Uji reliabilitas dari suatu variable dianggap lolos apabila nilai alpha lebih besar dari 0.7, sedangkan nilai yang didapat dari uji reliabilitas variable pendayagunaan zakat adalah 0.763 .

\section{Uji Asumsi}

Uji asumsi yang digunakan untuk model regresi adalah uji normalitas, multikolinieritas dan heteroskedastisitas. Dari uji asumsi yang didapat adalah

\section{Normalitas}

Tabel 1. Uji Normalitas

One-Sample Kolmogorov-Smirnov Test

\begin{tabular}{|ll|r|}
\hline & & Unstandardized Residual \\
\hline N & & 99 \\
& Mean & .0000000 \\
Most Extreme Differences & Absolute & .02674427 \\
& Positive & .136 \\
& Negative & .077 \\
Kolmogorov-Smirnov Z & & -.136 \\
Asymp. Sig. (2-tailed) & & 1.348 \\
a. Test distribution is Normal. & .053 \\
\hline
\end{tabular}

Dari table di atas menunjukkan bahwa instrument yang digunakan dalam penelitian tersebut adalah berdistribusi normal 


\section{Multikolinieritas}

Multikolinieritas adalah keadaan dimana terjadi hubungan linier yang sempurna atau mendekati sempurna antar variabel independen dalam model regresi. Uji multikolinieritas digunakan untuk mengetahui ada atau tidaknya hubungan linier antar variabel independen dalam model regresi. Prasyarat yang harus dipenuhi dalam model regresi adalah tidak adanya multikolinieritas. Ada beberapa metode pengujian yang bisa digunakan antara lain :

a. Dengan melihat nilai inflation factor (VIF) pada model regresi

b. Dengan membandingkan nilai koefisien determinasi individual $\left(\mathrm{r}^{2}\right)$ dengan nilai determinasi secara serentak $\left(R^{2}\right)$

c. Dengan melihat nilai Eigenvalue dan condition index

Pada pembahasan ini akan dilakukan uji multikolinieritas dengan melihat IF lebih besar dari 5 maka variabel tersebut mempunyai persoalan multikolinieritas dengan variabel bebas lainnya.

Tabel 2. Uji Multikolinieritas

\begin{tabular}{|c|c|c|c|c|c|c|c|c|}
\hline \multicolumn{9}{|c|}{ Coefficients ${ }^{a}$} \\
\hline & & \multicolumn{2}{|c|}{ Unstandardized Coefficients } & $\begin{array}{l}\text { Standardized } \\
\text { Coefficients }\end{array}$ & \multirow[b]{2}{*}{$\mathrm{t}$} & \multirow[b]{2}{*}{ Sig. } & \multicolumn{2}{|c|}{ Collinearity Statistics } \\
\hline \multicolumn{2}{|c|}{ Model } & B & Std. Error & Beta & & & Tolerance & VIF \\
\hline \multirow[t]{3}{*}{1} & (Constant) & .598 & .070 & & 8.527 & .000 & & \\
\hline & $\mathrm{x} 1$ & .501 & .066 & .579 & 7.565 & .000 & .699 & 1.430 \\
\hline & $x 2$ & .006 & .002 & .292 & 3.812 & .000 & .699 & 1.430 \\
\hline
\end{tabular}

a. Dependent Variable: $\mathrm{y}$

Dari table diatas didapat nilai VIF tidak lebih dari 5 maka tidak ada masalah dari uji multikolinieritas

\section{Heteroskedastisitas}

Uji heteroskedastisitas ini digunakan untuk mengetahui ada atau tidaknya ketidaksamaan varian dari residual pada model regresi. Prasyarat yang harus dipenuhi dalam model regresi adalah tidak adanya masalah heteroskedastisitas. Ada beberapa metode pengujian yang bias digunakan yaitu : Uji Spearman's rho, Uji Glejser, dan Uji Park. Pada pembahasan ini akan dilakukan uji heteroskedastisitas dengan menggunakan Uji Spearman's rho, yaitu mengkorelasikan nilai residual (Unstandardized residual) dengan masing-masing variable independent. Jika signifikansi korelasi kurang dari 0.05 maka pada model regresi terjadi masalah heteroskedastisitas.

\section{Tabel 3. Uji Heteroskedastisitas}

Correlations

\begin{tabular}{|rll|r|r|r|}
\hline & & $\mathrm{x} 1$ & $\mathrm{x} 2$ & Unstandardized Residual \\
\hline Spearman's rho & $\mathrm{x} 1$ & Correlation Coefficient & 1.000 & $.545^{* *}$ & .011 \\
& & Sig. (2-tailed) &. & .000 & .916 \\
& $\mathrm{~N}$ & 99 & 99 & 99 \\
\cline { 2 - 5 } & $\mathrm{N} 2$ & Correlation Coefficient & $.545^{* *}$ & 1.000 & -.046 \\
& Sig. (2-tailed) & .000 & .652 \\
\hline
\end{tabular}




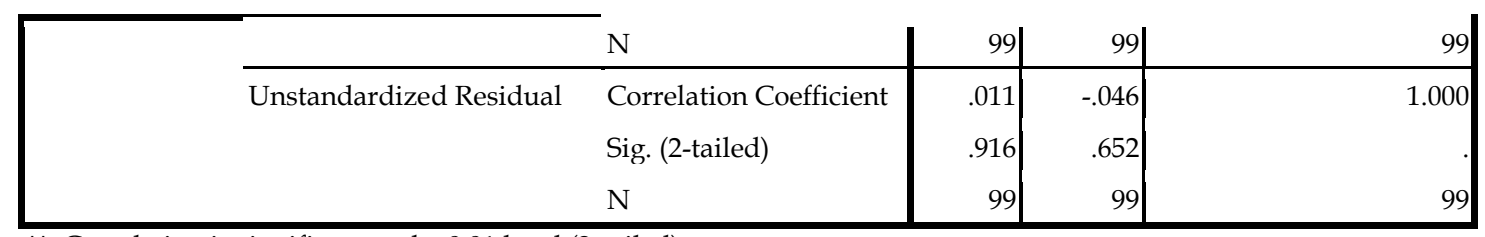

**. Correlation is significant at the 0.01 level (2-tailed).

Dari output korelasi di atas dapat diketahui bahwa korelasi antara PER dengan Unstandardized Residual menghasilkan nilai signifikansi 0.916 dan korelasi antara ROI dengan Standardized Residual menghasilkan nilai signifikansi 0.652. karena nilai signifikansi korelasi lebih besar dari 0.05, maka dapat disimpulkan bahwa pada model regresi tidak ditemukan adanya masalah heteroskedastisitas

\section{Analisis Regresi}

Analisis regresi linier berganda adalah hubungan secara linear antara dua atau lebih variabel independen $\left(X_{1}, X_{2}, \ldots . X_{n}\right)$ dengan variabel dependen (Y). Analisis ini untuk mengetahui arah hubungan antara variabel independen dengan variabel dependen apakah masing-masing variabel independen berhubungan positif atau negatif dan untuk memprediksi nilai dari variabel dependen apabila nilai variabel independen mengalami kenaikan atau penurunan. Data yang digunakan biasanya berskala interval atau rasio.

Persamaan regresi linear berganda sebagai berikut:

$Y^{\prime}=a+b_{1} X_{1}+b_{2} X_{2}+\ldots . .+b_{n} X_{n}$

Keterangan:

$\mathrm{Y}^{\prime}=$ Pengentasan Kemiskinan

$\mathrm{X}_{1}=$ Potensi Zakat

$\mathrm{X}_{2}=$ Pendayagunaan Zakat

a $=$ Konstanta

$\mathrm{b}=$ Koefisien regresi

Tabel 4. Regresi

Coefficients ${ }^{a}$

\begin{tabular}{|c|c|c|c|c|c|c|c|}
\hline \multirow[b]{2}{*}{ Model } & \multicolumn{2}{|c|}{$\begin{array}{l}\text { Unstandardized } \\
\text { Coefficients }\end{array}$} & \multirow{2}{*}{\begin{tabular}{|c|}
$\begin{array}{c}\text { Standardized } \\
\text { Coefficients }\end{array}$ \\
Beta \\
\end{tabular}} & \multirow[b]{2}{*}{$\mathrm{t}$} & \multirow[b]{2}{*}{ Sig. } & \multicolumn{2}{|c|}{$\begin{array}{l}\text { Collinearity } \\
\text { Statistics }\end{array}$} \\
\hline & B & Std. Error & & & & Tolerance & VIF \\
\hline (Constant) & .598 & .070 & & 8.527 & .000 & & \\
\hline$x 1$ & .501 & .066 & .579 & 7.565 & .000 & .699 & 1.430 \\
\hline$x 2$ & .006 & .002 & .292 & 3.812 & .000 & 699 & 1.430 \\
\hline
\end{tabular}

a. Dependent Variable: $\mathrm{y}$

$\mathrm{Y}^{\prime}=\mathrm{a}+\mathrm{b}_{1} \mathrm{X}_{1}+\mathrm{b}_{2} \mathrm{X}_{2}$

$Y^{\prime}=0.598+0.501 X_{1}+0.006 X_{2}$

Keterangan:

Persamaan regresi di atas dapat dijelaskan sebagai berikut: 
Konstanta sebesar 0.598; artinya jika Potensi Zakat $\left(\mathrm{X}_{1}\right)$ dan Pendayagunaan Zakat $\left(\mathrm{X}_{2}\right)$ nilainya adalah 0, maka Pengentasan Kemiskinan $\left(Y^{\prime}\right)$ nilainya adalah 0.598 .

\section{Analisis Korelasi Ganda (R)}

Analisis ini digunakan untuk mengetahui hubungan antara dua atau lebih variabel independen $\left(X_{1}, X_{2}, \ldots X_{n}\right)$ terhadap variabel dependen $(Y)$ secara serentak. Koefisien ini menunjukkan seberapa besar hubungan yang terjadi antara variabel independen $\left(X_{1}, X_{2}, \ldots . . X_{n}\right)$ secara serentak terhadap variabel dependen $(Y)$. nilai $R$ berkisar antara 0 sampai 1 , nilai semakin mendekati 1 berarti hubungan yang terjadi semakin kuat, sebaliknya nilai semakin mendekati 0 maka hubungan yang terjadi semakin lemah.

Menurut Sugiyono (2007) pedoman untuk memberikan interpretasi koefisien korelasi sebagai berikut:
$0,00-0,199=$ sangat rendah
$0,20-0,399=$ rendah
$0,40-0,599=$ sedang
$0,60-0,799=$ kuat
$0,80-1,000 \quad=$ sangat kuat

Dari hasil analisis regresi, lihat pada output moddel summary dan disajikan sebagai berikut:

Tabel 5. Hasil analisis korelasi ganda

Model Summaryb

\begin{tabular}{|l|r|r|r|r|r|}
\hline $\begin{array}{l}\text { Mode } \\
1\end{array}$ & R & R Square & $\begin{array}{c}\text { Adjusted R } \\
\text { Square }\end{array}$ & $\begin{array}{l}\text { Std. Error of } \\
\text { the Estimate }\end{array}$ & $\begin{array}{l}\text { Durbin- } \\
\text { Watson }\end{array}$ \\
\hline 1 & $.779 \mathrm{a}$ & .606 & .598 & .02702 & 1.755 \\
\hline
\end{tabular}

a. Predictors: (Constant), x2, x1

b. Dependent Variable: $y$

Berdasarkan tabel di atas diperoleh angka $\mathrm{R}$ sebesar 0,779. Hal ini menunjukkan bahwa terjadi hubungan yang sangat kuat antara Potensi Zakat dan Pendayagunaan Zakat terhadap Pengentasan Kemiskinan.

\section{Analisis Determinasi ( $\left.\mathbf{R}^{2}\right)$}

Analisis determinasi dalam regresi linear berganda digunakan untuk mengetahui prosentase sumbangan pengaruh variabel independen $\left(X_{1}\right.$, $\left.\mathrm{X}_{2}, \ldots . . \mathrm{X}_{\mathrm{n}}\right)$ secara serentak terhadap variabel dependen $(\mathrm{Y})$. Koefisien ini menunjukkan seberapa besar prosentase variasi variabel independen yang digunakan dalam model mampu menjelaskan variasi variabel dependen. $\mathrm{R}^{2}$ sama dengan 0, maka tidak ada sedikitpun prosentase sumbangan pengaruh yang diberikan variabel independen terhadap variabel dependen, atau variasi variabel independen yang digunakan dalam model tidak menjelaskan 
sedikitpun variasi variabel dependen. Sebaliknya $\mathrm{R}^{2}$ sama dengan 1 , maka prosentase sumbangan pengaruh yang diberikan variabel independen terhadap variabel dependen adalah sempurna, atau variasi variabel independen yang digunakan dalam model menjelaskan $100 \%$ variasi variabel dependen.

Dari hasil analisis regresi, lihat pada output moddel summary dan disajikan sebagai berikut:

Tabel 6. Hasil analisis determinasi

Model Summary $b$

\begin{tabular}{|l|r|r|r|r|r|}
\hline $\begin{array}{l}\text { Mode } \\
1\end{array}$ & $\mathrm{R}$ & R Square & $\begin{array}{c}\text { Adjusted R } \\
\text { Square }\end{array}$ & $\begin{array}{l}\text { Std. Error of } \\
\text { the Estimate }\end{array}$ & $\begin{array}{l}\text { Durbin- } \\
\text { Watson }\end{array}$ \\
\hline 1 & $.779 \mathrm{a}$ & .606 & .598 & .02702 & 1.755 \\
\hline
\end{tabular}

a. Predictors: (Constant), x2, x1

b. Dependent Variable: $y$

Berdasarkan tabel di atas diperoleh angka $\mathrm{R}^{2}$ (R Square) sebesar 0,598 atau $(59,8 \%)$. Hal ini menunjukkan bahwa prosentase sumbangan pengaruh variabel independen Potensi Zakat dan Pendayagunaan Zakat terhadap variabel dependen (Pengentasan Kemiskinan) sebesar 59,8\%. Atau variasi variabel independen yang digunakan dalam model (PER dan ROI) mampu menjelaskan sebesar 59,8\% variasi variabel dependen (pengentasan Kemiskinan). Sedangkan sisanya sebesar 40,2\% dipengaruhi atau dijelaskan oleh variabel lain yang tidak dimasukkan dalam model penelitian ini.

Adjusted R Square adalah nilai R Square yang telah disesuaikan, nilai ini selalu lebih kecil dari $\mathrm{R}$ Square dan angka ini bisa memiliki harga negatif. Menurut Santoso (2001) bahwa untuk regresi dengan lebih dari dua variabel bebas digunakan Adjusted $\mathrm{R}^{2}$ sebagai koefisien determinasi.

\section{Uji Koefisien Regresi Secara Bersama-sama (Uji F)}

Uji ini digunakan untuk mengetahui apakah variabel independen $\left(\mathrm{X}_{1}, \mathrm{X}_{2} \ldots \mathrm{X}_{\mathrm{n}}\right)$ secara bersama-sama berpengaruh secara signifikan terhadap variabel dependen (Y). Atau untuk mengetahui apakah model regresi dapat digunakan untuk memprediksi variabel dependen atau tidak. Signifikan berarti hubungan yang terjadi dapat berlaku untuk populasi (dapat digeneralisasikan) Dari hasil output analisis regresi dapat diketahui nilai $\mathrm{F}$ berikut ini.

Tabel 7. Hasil Uji F

ANOVA $^{b}$

\begin{tabular}{|ll|r|r|r|l|l|}
\hline Model & Sum of Squares & \multicolumn{1}{c|}{$\mathrm{df}$} & Mean Square & $\mathrm{F}$ & Sig. \\
\hline 1 & Regression & .108 & 2 & .054 & 73.889 & $.000^{\mathrm{a}}$ \\
& Residual & .070 & 96 & .001 & & \\
Total & .178 & 98 & & & \\
\hline
\end{tabular}

a. Predictors: (Constant), x2, x1

b. Dependent Variable: $y$ 
Kesimpulan yang didapat dari uji $\mathrm{F}$ adalah $\mathrm{F}$ hitung $>\mathrm{F}$ tabel $(73.889>$ 3,09), dengan demikian Ho ditolak, artinya ada pengaruh secara signifikan antara Potensi Zakat dan Pendayagunaan Zakat secara bersama-sama terhadap terhadap Pengentasan Kemiskinan.

\section{Uji Koefisien Regresi Secara Parsial (Uji t)}

Uji ini digunakan untuk mengetahui apakah dalam model regresi variabel independen $\left(X_{1}, X_{2}, \ldots . . X_{n}\right)$ secara parsial berpengaruh signifikan terhadap variabel dependen $(\mathrm{Y})$.

Dari hasil analisis regresi output dapat disajikan sebagai berikut:

Tabel 8. Uji t

Coefficients $^{a}$

\begin{tabular}{|c|c|c|c|c|c|c|c|}
\hline \multirow[b]{2}{*}{ Model } & \multicolumn{2}{|c|}{$\begin{array}{c}\text { Unstandardized } \\
\text { Coefficients }\end{array}$} & \multirow{2}{*}{\begin{tabular}{|c|}
$\begin{array}{c}\text { Standardized } \\
\text { Coefficients }\end{array}$ \\
Beta \\
\end{tabular}} & \multirow[b]{2}{*}{$\mathrm{t}$} & \multirow[b]{2}{*}{ Sig. } & \multicolumn{2}{|c|}{$\begin{array}{c}\text { Collinearity } \\
\text { Statistics }\end{array}$} \\
\hline & B & $\begin{array}{l}\text { Std. } \\
\text { Error }\end{array}$ & & & & Tolerance & VIF \\
\hline $\begin{array}{ll}1 \quad \text { (Consta } \\
\text { nt) }\end{array}$ & .598 & .070 & & 8.527 & .000 & & \\
\hline$x 1$ & .501 & .066 & .579 & 7.565 & .000 & .699 & 1.430 \\
\hline$x 2$ & .006 & .002 & .292 & 3.812 & .000 & .699 & 1.430 \\
\hline
\end{tabular}

a. Dependent

Variable: y

\section{Pengujian koefisien regresi variabel Potensi Zakat}

Kesimpulan yang didapat dari uji $\mathrm{t}$ adalah nilai $\mathrm{t}$ hitung $>\mathrm{t}$ table (7.565> 1.98) maka Ho ditolak, artinya secara parsial ada pengaruh signifikan antara Potensi Zakat dengan Pengentasan Kemiskinan.

\section{Pengujian koefisien regresi variabel Pendayagunaan Zakat}

Kesimpulan yang didapat dari uji $\mathrm{t}$ adalah nilai $\mathrm{t}$ hitung $>\mathrm{t}$ tabel (3.812> 1.98) maka Ho ditolak, artinya secara parsial ada pengaruh signifikan antara Pendayagunaan Zakat dengan Pengentasan Kemiskinan.

\section{SIMPULAN DAN SARAN}

Kesimpulan

Berdasarkan hasil penelitian sebagaimana dikemukakan pada BAB sebelumnya, dapat ditarik kesimpulan sebagai berikut :

1. Menurut hasil penelitian ini sumbangan pengaruh dari variabel Potensi Zakat dan Pendayagunaan Zakat adalah sebesar 59,8\% variasi variabel dependen (pengentasan Kemiskinan). Sedangkan sisanya sebesar 40,2\% 
dipengaruhi atau dijelaskan oleh variabel lain yang tidak dimasukkan dalam model penelitian ini.

2. Secara simultan variabel yang digunakan dalam penelitian ini (secara bersama-sama berpengaruh terhadap Pengentasan Kemiskinan.

\section{Saran}

Penelitian ini jauh dari sempurna maka bagi peneliti yang akan melakukan penelitian serupa disarankan untuk menambah variabel yang lebih banyak dan jangka waktu yang lebih lama, sehingga lebih representative dan lebih valid

\section{DAFTAR PUSTAKA}

Beik IS. 2009. Analisis Peran Zakat dalam Mengurangi Kemiskinan: Studi Kasus Dompet Dhuafa Republika. Jurnal Zakat \& Empowering

Badan Pusat Statistik kota Pekalongan

Nurzaman MS. 2010. Zakat and human development: an empirical analysis on poverty alleviation in Jakarta, indonesia. Center for Islamic economics and finance, Qatar faculty of Islamic studies, Qatar foundation 